MATTER: International Journal of Science and Technology

ISSN 2454-5880

Francesco Martinazzo, 2022

Volume 7 Issue 3, pp. 94-111

Received: 03' June 2021

Revised: 05 ${ }^{\text {th }}$ November 2021, 11 th November 2021, 31 ${ }^{\text {st }}$ January 2022

Accepted: 31 ${ }^{\text {st }}$ January 2022

Date of Publication: 02 ${ }^{\text {nd }}$ February 2022

DOI- https://doi.org/10.20319/mijst.2022.73.94111

This paper can be cited as: Martinazzo, F. (2022). The "School-Machine" Through the Architecture

Magazines of the Sixties and Seventies. MATTER: International Journal of Science and Technology, 7

(3), 94-111.

This work is licensed under the Creative Commons Attribution-NonCommercial 4.0 International License.

To view a copy of this license, visit http://creativecommons.org/licenses/by-nc/4.0/ or send a letter to Creative Commons, PO Box 1866, Mountain View, CA 94042, USA

\title{
THE "SCHOOL-MACHINE" THROUGH THE ARCHITECTURE MAGAZINES OF THE SIXTIES AND SEVENTIES
}

\author{
Francesco Martinazzo \\ MD, Politecnico di Milano, Milan, Italy \\ francesco.martinazzo@polimi.it
}

\begin{abstract}
If we retrace the fundamental stages of the history of education, we notice how school, with "Distance Teaching”, seems to be in a kind of zero degrees of education. From the one-to-one relationship of Socrates with his students, we find ourselves today in a situation similar to the first, but in which the teacher and the pupil disappear from the physical space, to appear in the screen of a technological device. However, much of the student's education passes through the school space as an educational environment, both because of the social relationships it brings with it and because of the space's intrinsic capacity to encourage or hinder well-being. The research reflects on the concept of "school-machine", born in the sixties, where technology is not applied a posteriori to the building, but the building itself is conceived as a technological-typological device at the service of learning. To clarify this definition, school projects have been cataloged by methodically scanning the international architecture magazines of the 1960s and 1970s. These examples want to be presented to stimulate a reflection on the way the school can be rethought for
\end{abstract}


MATTER: International Journal of Science and Technology

ISSN 2454-5880

the post-COVID era as strategic infrastructure, illuminating the many analogies between that season and ours.

\section{Keywords}

Learning Center, Teaching Machine, Technology, EFL

\section{Introduction}

In Italy, the summer of 2020 was the scene of a heated political debate on the organization of schools and education (especially compulsory education) due to the issues surrounding Covid 19. This debate resulted in the new guidelines of the government (MIUR, 2020), which called for less face-to-face teaching and more workshop teaching, in small groups and not necessarily in the classroom, but also in different spaces to combine the need for distance with innovation. They also called for the purchase of new furniture, such as new-generation individual desks (with castors) to enable more collaborative teaching and the integration of digital teaching with face-to-face teaching.

However, despite the good intentions, the guidelines were disregarded by the autumn pandemic, which delegated education almost entirely to online. Thus, with the arrival of spring and the fading of the contagion, thanks to warmth and vaccines, and with a change of government in the meantime, the PNRR (National Recovery and Resilience Plan), and the chapter devoted to education ("mission 4") are being discussed. The reforms envisaged in the PNRR include a total investment in schools of 20 billion euros over five years. Among the reforms envisaged is a reduction in the number of pupils per class and the overcoming of age-based classes, in favor of groups based on level of ability, typical of the Anglo-Saxon model (Gavosto, 2020). As far as interventions on school buildings are concerned, on the other hand, the total amount envisaged is 8 billion, which should concern building interventions for the renovation and modernization of structures, as well as the transition to School 4.0. Well, it does not take long to realize that such measures, if implemented, would constitute a true Copernican revolution for Italian schools. They would lead to a radical rethinking of the very foundations on which the current school rests, involving all spheres of public education, from building to teaching. But are all these fine proposals so 'state-of-the-art'? Are they as innovative as they are being 'painted' by their promoters and the media? The answer is probably "no". It is enough to leaf through the architecture magazines of the 60 s and 70 s to realize that, in reality, these issues were already being discussed and on the agenda 
at the time, with results that were sometimes positive, sometimes negative, as in several Italian examples, precisely because of the unpreparedness of teachers and the entire system to accept such a high degree of change. One need only leaf through the advertisements in magazines such as Progressive Architecture or Architectural Forum to realize that desks on wheels, movable walls, and attempts to rationalize the use of new technologies (such as TV) in teaching programmers were the order of the day in those years. If we then leaf through the recent INDIRE (Istituto Nazionale Documentazione Innovazione Ricerca Educativa) publications (INDIRE, 2013) on educational spaces for the school of the third millennium, summarized as group space, individual space, exploration space, agora, informal space; it becomes clear that the current themes (MIUR, 2013) are nothing but pale imitations of ideas that have been explored during a good part of the past century (English, 2005), but which are still struggling to take hold, despite all the attempts made, because, to use the words of Erwin Panofsky, "the mental habitus" of western societies is not yet ready. I will therefore attempt in this paper to retrace the fundamental stages of school experimentation with new technologies and the architecture capable of accommodating them, in the hope of better understanding the processes underway today. Since technologies - both concerning pedagogical devices and constructive possibilities - have made great strides in recent years, a comparison capable of reclining valid themes of the past to the present seems essential for the structuring of large-scale reasoning of the existing school heritage (Ehrenkrantz, 1999).

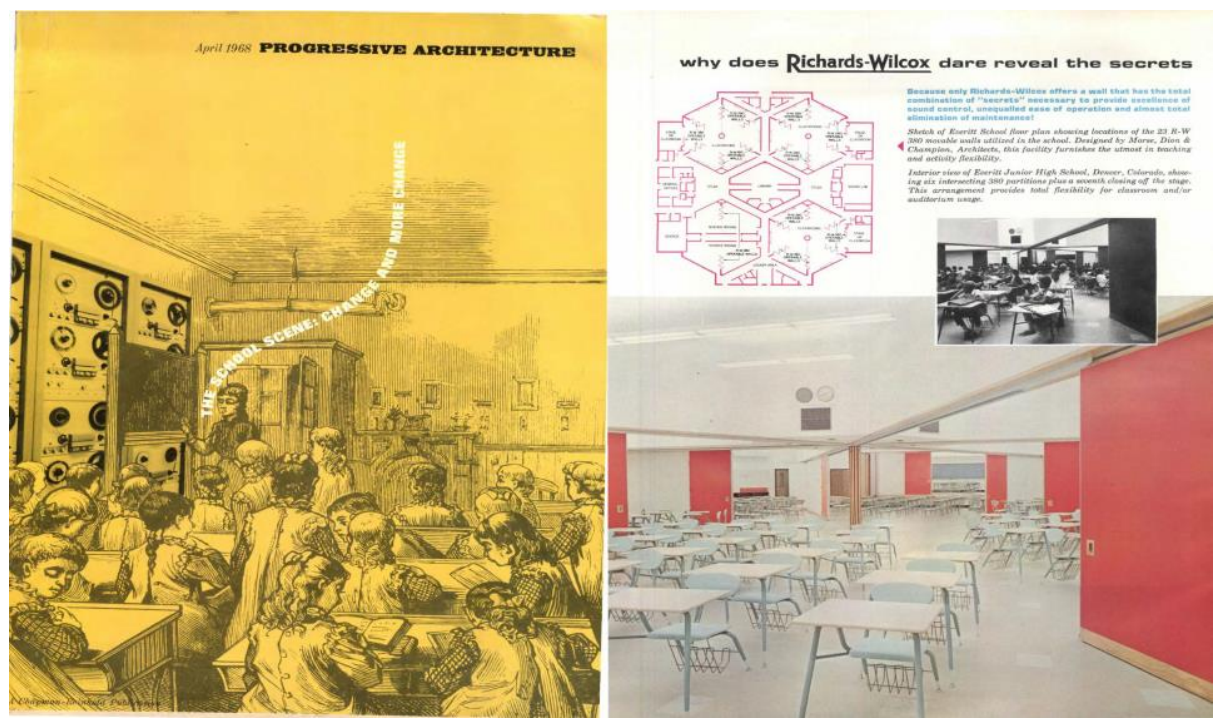

Figure 1: Cover of an April 1968 issue of Progressive Architecture and advertisement for a school with movable walls.

(Source: Progressive Architecture, Volume XLIX, n.4, April 1968.) 


\section{Literature Review}

Facilities should be more sensitively designed to the new needs of education in a period of rapid, revolutionary change in instruction and social conditions. An intelligent economy should be encouraged wherever, whenever, and however, it could be.

(Graves, 1993)

EFL, working with educators, architects, and suppliers, studied and promoted the use of folding and moveable walls to gain the advantages offlexible space, investigated and funded examples of "systems" building components to build schools faster, cheaper, and better, explored the use of new media, especially television, and studied how they might influence school design, and encouraged school systems to try new organizational methods such as team teaching, new curricula, and new relationships within their communities.

(Brubaker, 1998)

One of the most important and structured examples, in my opinion, of the use of technology in education and the resulting school design, comes from the second half of the last century and concerns the events linked to the EFL, an American non-profit institution.

With the end of the Second World War and the baby boom that followed, the population of the United States experienced a sharp increase in birth rates. This led to an urgent need for new school facilities as projections for the late 1950s predicted about 2 million students over available places, with a projected expenditure on buildings (to bring them up to standard) of about 40 billion dollars.

So, in 1953, the American Institute of Architects decided to set up the Committee on School Buildings to deal with the serious situation. But the turning point came when, in 1956, the Committee was joined by a group of scholars from Columbia University's Teachers College, who came up with the idea of applying for funds directly from the Ford Foundation to study school buildings. Fortunately, as James Armsey wrote retrospectively in 1976, "they had been searching for some means of solidifying and institutionalizing ways of ridding the education establishment of its attachment to forms and methods that they believed were hamstringing the teaching-learning process, proposing that it was easier to change buildings and what went into them than to change people" (Armsey, 1976). And so the Ford Foundation decided to create an independent non-profit body, the Education Facilities Laboratories. It lasted from 1958 to 1986, 28 years, strongly influencing all US and Canadian educational achievements of that period, but it also had a strong international echo because of the many wise publications, which besides Scientific Reports and 
Papers, also included Films. In all, the EFL publications include more than 100 reports, six series, four newsletters.

As one of its directors, Alfred Weinstock, stated, "Our job, didn't just deal with the things of education, but with the feeling of the schoolhouse as a whole, as a total environment that could deeply affect learning and growth" (Weinstock, 1999). Similarly, the themes within EFL were varied and can perhaps be summarized under the slogan of 'aggressive philanthropy', as the members of the organization themselves liked to call their approach. One of the determining factors of EFL was indeed the ability to bring architects, designers, builders, entrepreneurs, educators, and school staff together around a table, in the belief that educational changes always lead to architectural consequences.

Back in 1972, Eric Pearson said that "rather than offering a conventional and anonymous solution with classrooms and corridors, the space was intentionally divided into a series of complementary learning areas, each with a specific function and value that invited a particular activity" (Pearson, 1972).

Thus, among the organization's activities, research on the Open Plan, School Libraries, and Building Systems played a decisive role; which, combined with Team Teaching, a new and collaborative system of teaching, in which each teacher deals with the practical or theoretical subjects in which he or she is best prepared, promised unexpected and experimental results (Arnold and Rand, 1979).

If in the first case (that of the open plan), the architectural concept is still very valid and used today, having produced at the time sometimes positive results, sometimes negative due to the "resistance" opposed by a school staff disoriented by so much novelty (Lee, 2019). The second introduced the great novelty of the Carrels for individual study, which, aided by the new technologies, led to the enhancement of the Library space, identified as the symbolic core of learning and relaxation. Finally, the third, initially borrowing certain British experiences, led to the School Construction System Development, to study a standardized but flexible construction system for school buildings. In an interview in 1969, the architect responsible for the project on these systems, Ehrenkrantz, described the SCSD in this way:

"Buildings that are erected as part of the SCSD program offer a tremendous variety in terms of expression, design, and design philosophy. We see SCSD as the beginning of evolution within 
the building industry — where options are available to architects and educators and where different levels of performance have known cost levels. I see SCSD as an approach towards better precision in the design process to determine what is wanted in a building and to develop the tools to utilize available resources in an optimal way" (Ehrenkrantz 1969). Although exterior walls were not considered by this system, they included structural, plant, lighting, and interior partition systems, giving rise to the idea of the Teaching Machine, or School Machine (Marks, 2009).

It would take too much time to go into these matters here, and I do not wish to be exhaustive on the specific issues, which should be dealt with separately. However, years later, the question arises as to whether these studies, which are still very valid at least on a conceptual level, have been taken into account. We need only think of one of the EFL researches, the one on the pedagogue J. Lloyd Trump, who, to cope with a great shortage of teachers, attempted to reorganize the entire national school system around principles of student empowerment, undermining the classroom to make way for differentiated forms of learning, either individual or in groups, and delegating the frontal lesson to seminars with several classes at the same time and teachers specially trained in theory. This avoids the need for a teacher to repeat the same lesson several times to different classes. Moreover, since Trump has delegated the design of meta-schools to lead architects, there are several designs and architectural examples of how such pedagogical ideas can have an effective impact on the quality of spaces.

In short, the school should be understood as an infrastructure of knowledge, a space that can organize knowledge in places with different characteristics, with the capacity, since architecture is a language, to make meaning. Space is of interest to pedagogy and didactics in that it is not a passive or neutral container but an active object of education, since it conveys information, discloses meanings, reveals values; and thus appears as a methodological device expressing the school's educational approach. This relationship with space lies in living, the fundamental characteristic of which is care, custody, and cultivation (Gores, 1970). 


\subsection{Research Issues}

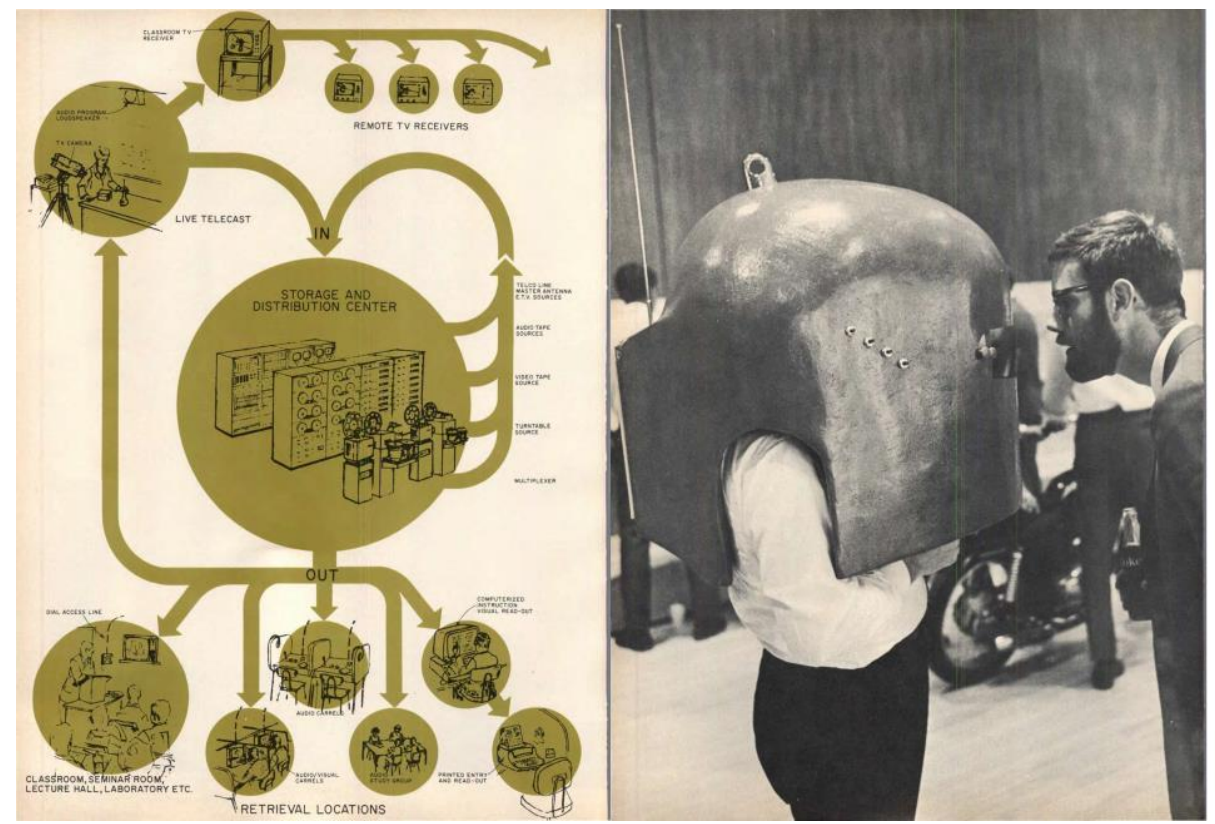

Figure 2: Diagram of the functioning of technological devices that appeared in the April 1968 issue of Progressive Architecture and experiments with television viewers.

(Source: Progressive Architecture, Volume XLIX, n.4, April 1968.)

If up to the 1960s the American technological experiments referred more to the plant engineering aspects, designating to the technological devices for teaching specific areas of the school building; with the end of the decade, a real technological turning point took place, leading to talk of a second-generation teaching machines. Although many people at the time questioned the electronic tools used in teaching, preferring the old, cheaper, and teaching machine safer teaching systems, the supporters of the new teaching justified the failures of the first experiments by saying that they had not dared to go far enough. New rooms and new machines, they said, are not enough to break the old, inefficient patterns of teaching and learning: people are infinitely resourceful in adapting old habits to new structures, which is why new structures sometimes fail.

But as the discussions continued, a much more sophisticated technology of learning systems was already emerging: a whole new generation of school equipment that went far beyond the 'gadget' approach. The new machines were said to be able to utilize the increasingly acute knowledge that psychologists were gaining about learning processes, allowing teachers to overcome the old habits that so often seemed to hinder the efficient transfer of knowledge. These 
'second generation' machines, which interacted with each other and led to the concept of 'plug-in schools', had these characteristics in common:

- They were complex and versatile enough to allow self-directed learning and adaptable precisely to the individual needs of the students.

- They transferred the burden of flexibility for future curriculum changes from the school building to the machine itself. And the machines were designed to handle technological change with ease.

- They implied some profound changes in the way the school facility and even the school district were organized; for example, they suggested a centralized structure for the production and storage of programs coupled with an extensive network of communication channels in which individual learning stations could be 'plugged in' and arranged in the building according to convenience.

- They needed a powerful computer-aided programming program to make efficient use of both the students' time and the school facility.

- They could be used even more effectively in combination with the new automated catering systems that allowed flexible scheduling of student time for classes of varying lengths.

And once assembled they would generate three main spatial systems:

-The "live" study carrel for individual self-paced learning, with instant access to a vast store of audio, visual, or printed material.

-The computer-linked teaching station, which can be programmed to shape its output to the student's learning patterns in some ways more effective than a human private tutor could.

-The automatically sequenced lecture can close the gap between teacher and student by allowing frequent student responses to influence the course of the presentation. 


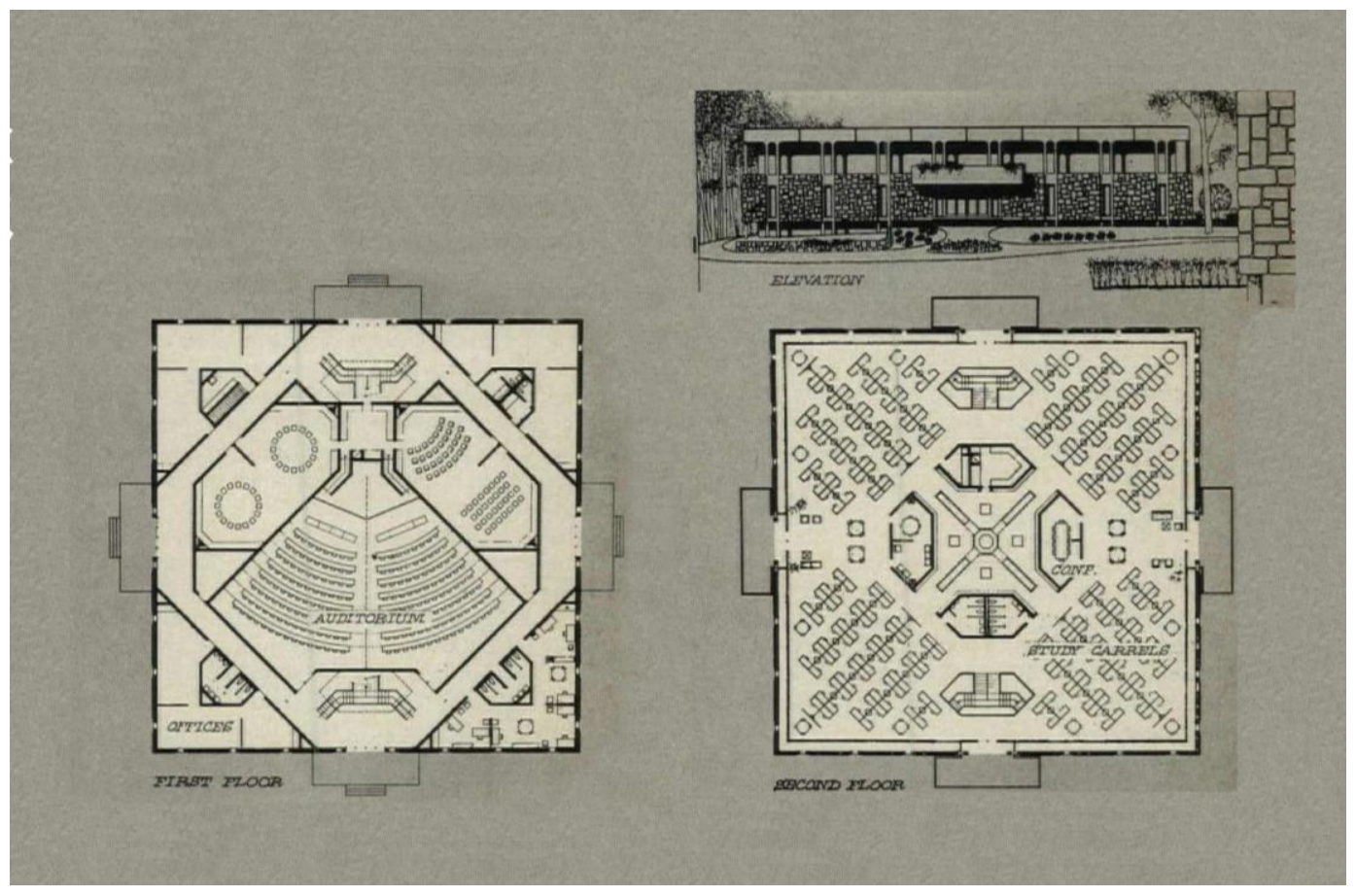

Figure 3: Unique "Learning Center" designed by Architects Meathe \& Kessler for Michigan's new Grand Valley State College.

(Source: Architectural Forum, Volume 116, n.4, August 1963.)

Examples of the practical application of such technologies include Michigan's Grand Valley State College, designed by architects Meathe and Kessler to accommodate up to 10,000 commuter students from small communities in western Michigan and nearby Grand Rapids (Architectural Forum, August 1963). The school was conceived around a radically new type of structure: the learning center. These 'learning centers' were 30,000-square-foot buildings, true selfsupporting liberal arts colleges. Each was designed around 256 divided classrooms equipped with an extensive audiovisual communications network (designed with the help of a grant from the Ford Foundation's Educational Facilities Laboratories mentioned earlier). The carrels were to provide instant access, through the rotation of a telephone dial, to any of the 17 videos and 80 audio channels provided. These channels contained an archive of live or stored presentations. Some of the audiotapes were left blank to record student comments or questions that were later taken up by faculty members. Cartridge-loaded audio and TV tapes multiplied the amount of material that each receiving station could reach. The educators who created the Grand Valley scheme believed that such resources could make self-study much more efficient and rewarding. 
Together with the associated classroom and lecture theatres, the four groups of 64 carrels in each learning center were to serve 512 students, each of whom would spend half their time in study carrels and half in group learning activities. But perhaps the most significant aspect of the experiment was the ability of this network to provide access to so much stored material, including lectures, that it freed up a great deal of the teachers' time to devote to academic work and the preparation of more effective programmers.

The system's designer himself, Sol Cornberg, a New York consultant with a long background in designing facilities for commercial television and theatre, realized that the high cost of the elaborate equipment was the main obstacle to wider use of the 'live' carrel. So, he designed one that could be built at a slightly higher cost than the standard school desk, believing that the savings in classroom space and faculty time would make the learning center less expensive than conventional school facilities in the long run.

The most promising tools in the new generation of teaching machines, however, were the gigantic electronic devices, already called 'computers' (a misnomer here, because it was for their logical network and storage capacity, rather than their computational ability, that they were useful in teaching).

This system required a skilled and sensitive teacher to program the machine, so a human was still at the heart of the system. Moreover, with the help of a computer, he could act as a private tutor for tens of thousands of students rather than as a teacher for a few. The computer was a very different kind of teaching machine from the flood of little black boxes that had appeared in those years. It had an enormous capacity to store knowledge, and it could move from one element to another in a complex pattern that responded to the learning habits of the individual student. At each step, the computer could be programmed to ask the student to read a section of a specially prepared text, or it could display sounds or images stored according to the nature of the student's previous response. The widespread use of technologically advanced teaching systems certainly brought with it a wider use of group teaching in the United States. Thanks to the collaboration of technology and team teaching, the usual class group of 30 people was in many cases abolished in favor of an individual study, discussion groups of 15 people, and large lectures for 150 people. Instead of the rigid division of the school day into uniform one-hour periods, many educators were 
able to organize time into 20-minute modules that allowed for student sessions of varying lengths. In this way, the time spent in class could be adapted to the subject to be studied.

Even lunch in many institutions could be delegated to a vending machine and eaten at any time nearby in a multi-purpose space. Scheduling was thus facilitated, and both the canteen and the kitchen were eliminated from the building, saving a lot of resources. Both hot and cold food was brought in from outside kitchens and kept at the right temperature by coin-operated vending machines, which were accessible throughout the school day.

We have therefore faced with a total (or almost total) mechanization of the school building. But while many of these experiments were designed for the conversion of existing buildings, there were many new projects in which architecture and technology sought new forms of collaboration, hitherto unimagined.

As electronic teaching systems became more and more widespread, the implications for school planning also became clearer. Whole school systems were imagined to be planned around central program production and storage facilities, which students in individual schools could access via an underground network (some suggested using the same network to distribute mechanical services, and even refills for vending machines). And if portable receiving stations could have been connected to the learning services network, a computer could have programmed periodic redistributions of such units to keep up with population movements.

In short, we are dealing with a proto-internalization of the school, which is still struggling to take off. But if we try to associate the technical-pedagogical reflections of the 60 s and 70 s with the most recent technological experiences in didactics, such as the way Seymour Papert tried all his life to make the child capable of programming the computer so as not to be a slave to it (Papert, 1998), or the digital exhibitions of the Reggio Children, in which it is the children who propose iconographic paths of discovery, designed by themselves, then perhaps we will be able to glimpse a way to counter the passivity of learning, which still reigns supreme in our schools. 


\section{Methodology}

Components

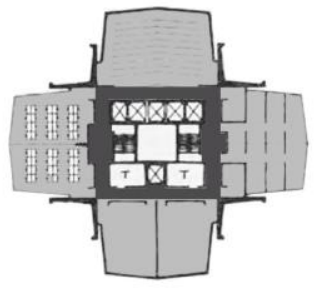

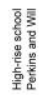

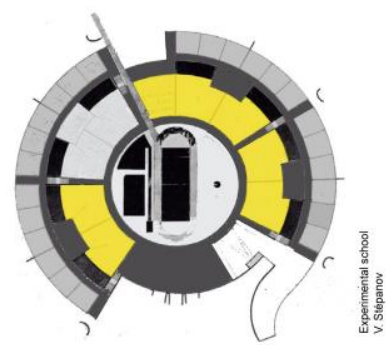

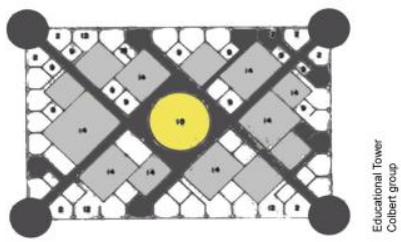
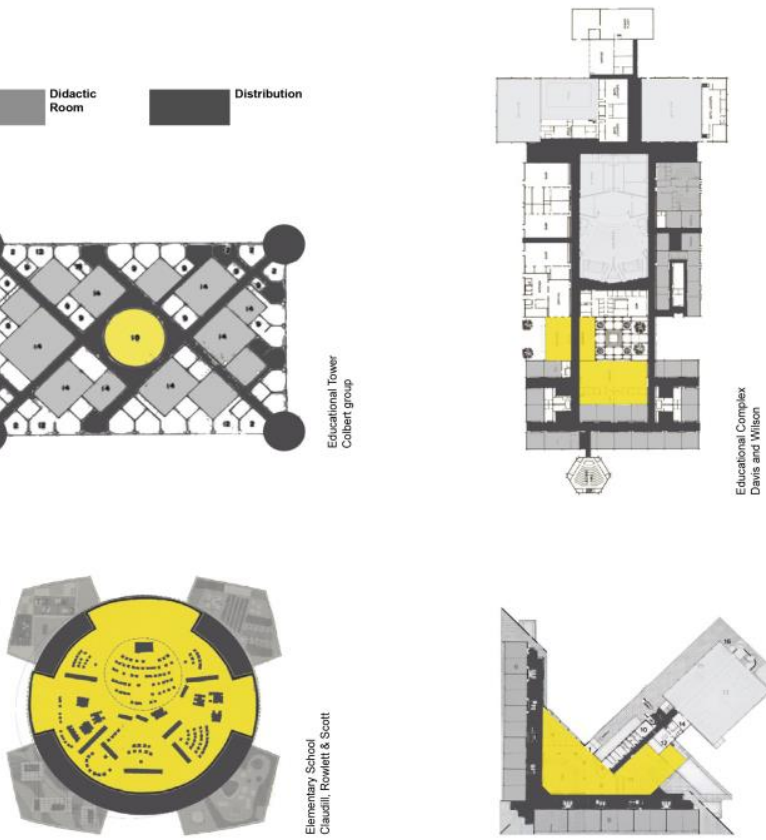

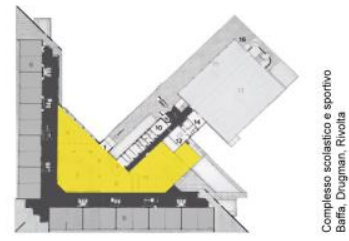

Figure 4: Personal elaboration of some examples of school-machine with their components.

(Source: personal drawing.)

In the light of what has been said, the research has been developed through the comparative analysis of case studies, obtained from the reconstruction of events and key figures of the sixties and seventies, which, due to the strong emphasis on the technological-typological problem linked to the school debate of those years, it was considered useful to relate to the most significant contemporary research, characterized by the same problems. The criterion for the choice of case studies is therefore based on the propulsive potential that they have about today's instances of transformation. The comparison also aims to develop an Atlas of Architectures useful for design today.

To draw up the Atlas, at this stage the research has concentrated mainly on consulting and cataloging international architectural journals. This research starts from the beautiful catalog of the traveling exhibition "CLIP, STAMP, FOLD", which reconstructs the editorial events of the architecture magazines of the 1960s-1970s, without however mentioning the schools. On the contrary, it presents a very rich list of journals, which can be defined as complete, and from which I started my consultation in the library. 
These examples from the 60s and 70s are intended to serve as picks for current issues and themes, to which a bibliographic search through Scopus sites, Web of Science, etc... and recent publications from foundations, research organizations, and universities are dedicated. These publications were selected based on the keywords listed in the first paragraph of this paper, through a cross-search. The titles and abstracts of the most promising papers were then analyzed.

\section{Conclusion}

If we believe that rediscovering past experiences (apparently forgotten) can help to understand how to solve current problems already faced in the past and not to repeat the same mistakes. While the use of technology, as seen in this paper, was very challenging and expensive in the past, both because of the costs and the large size of the devices used in the 60s and 70s, today they can be defined as "mass devices", and a single small smartphone is capable of handling infinitely more data than the old "wall-mounted" equipment. It is therefore natural to think of a "propulsive" use of technology, which can generate content and not just accumulate and sort it. It is almost as if one day students, whatever their age, will be able to virtually reconstruct their critical reasoning on the disciplines studied, going beyond the slavish repetition of topics learned mnemonically from the textbook. We imagine the school of the future as a video art workshop, an exhibition in which interpretations, readings, and contaminations between different subjects and fields can generate non-sectorial and limited thinking, but able to give life to the world of the future. To understand the potential of new technologies concerning learning environments, it is sufficient to look at the recent experiences of video art in museums and exhibitions, in the experiences of authors such as Studio Azzurro and Mammafotogramma, of works with a strong pedagogical charge. A "humanistic technique", at the service of the planet and man, of equality and democracy, capable of disseminating cultural content and involving society in processes of knowledge and cultural construction.

If in the current state of doctoral research there is still a lack of close comparison between past and current experiences, this will constitute the next evolution of the work, going to investigate the internal spatiality of individual school environments, in their sequence and interpenetration. The attempt will be to understand how - to the detriment of the latest trends in school architecture, all tending towards total spatial undifferentiation - it is still possible and urgent 
to think of a specific space for the various learning spaces, each with its own specific technical and design possibilities.

\begin{tabular}{|c|c|}
\hline \multicolumn{2}{|c|}{ CULLING OF JOURNALS } \\
\hline USA & \\
\hline \multicolumn{2}{|l|}{ Architectural Forum } \\
\hline & - 1960 Volume 112, n.3, March \\
\hline & $\begin{array}{l}\text { Three ace schools for the Trump Plan, Frank } \\
\text { Lots Miller }\end{array}$ \\
\hline & - 1960 Volume 114, n.5, May \\
\hline & $\begin{array}{l}\text { Big top for teaching, arch.Claudill, Rowlett \& } \\
\text { Scott }\end{array}$ \\
\hline & • 1961 Volume 115, n. 5, November \\
\hline & $\begin{array}{l}\text { Technology: Flexible teaching space, George } \\
\text { Zimbel }\end{array}$ \\
\hline & - 1963 Volume 116, n. 4, August \\
\hline & $\begin{array}{l}\text { Technology: the "plug-in" school, Bernard P. } \\
\text { Spring }\end{array}$ \\
\hline \multicolumn{2}{|l|}{ Progressive Architecture } \\
\hline & - 1968 Volume XLIX, n.4, April \\
\hline & $\begin{array}{l}\text { The school scene: change and more change, } \\
\text { Jean C. Roman }\end{array}$ \\
\hline & • 1972 Volume XLXIII, n.2, February \\
\hline & Space framing at Sanislo, James A. Murphy \\
\hline \multicolumn{2}{|l|}{ Perspecta } \\
\hline & - 1969 n.12, September \\
\hline & $\begin{array}{l}\text { Experimental Strategies: Notes for } \\
\text { Environmental Design, Melvin Charney }\end{array}$ \\
\hline & $\begin{array}{l}\text { The Environmental Game and Taking Part, } \\
\text { Julian Beinart }\end{array}$ \\
\hline \multicolumn{2}{|l|}{ UNITED KINGDOM } \\
\hline \multicolumn{2}{|l|}{ Architectural Review } \\
\hline & - 1960 Volume 127, n.758, April \\
\hline & $\begin{array}{l}\text { School at Richmond, Yorks, arch. Clarke-Hall } \\
\text { and Scorer }\end{array}$ \\
\hline & • 1960 Volume 127, n.765, November \\
\hline
\end{tabular}


MATTER: International Journal of Science and Technology

ISSN 2454-5880

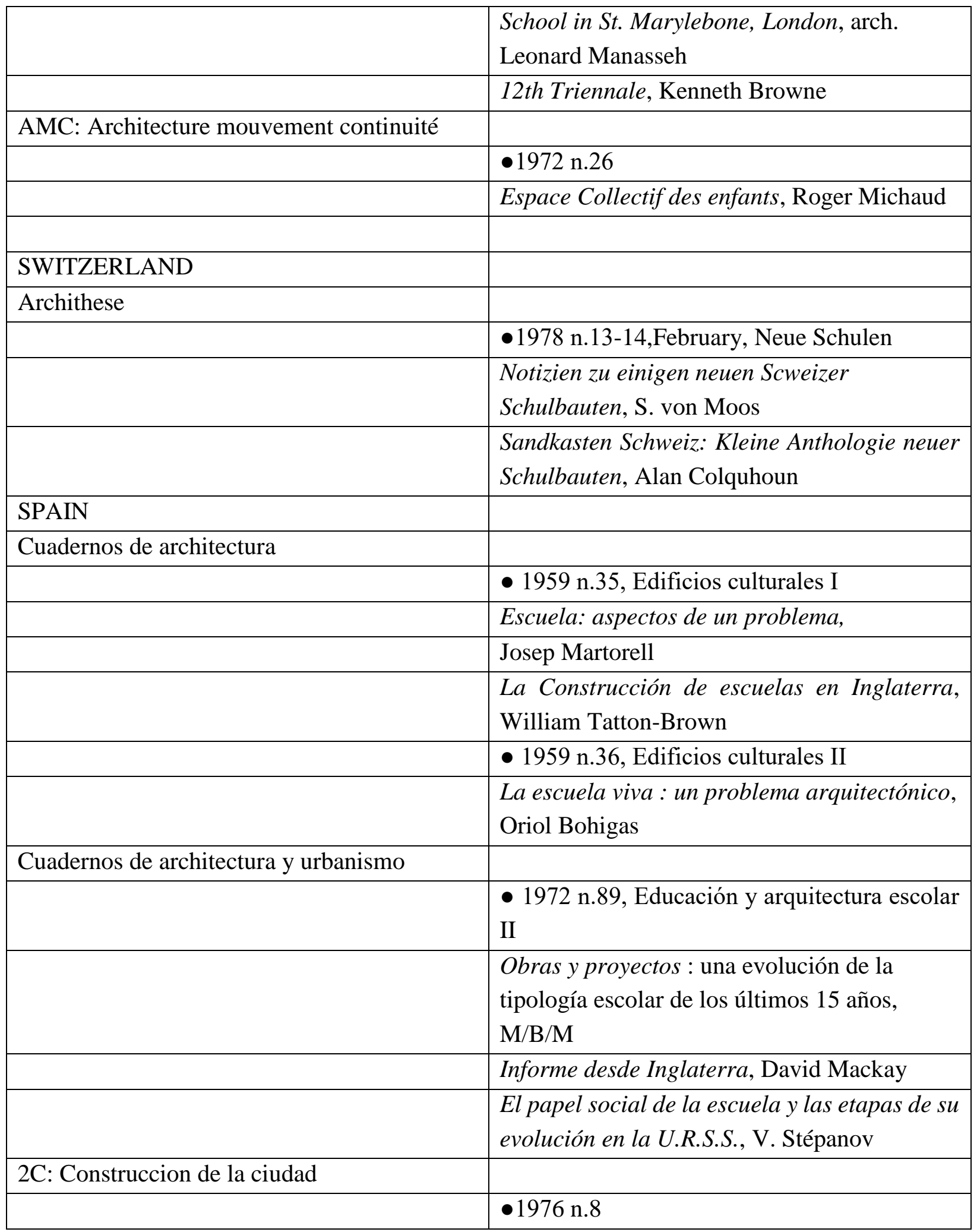




\begin{tabular}{|l|l|}
\hline & $\begin{array}{l}\text { Arquitectura Y Racionalismo, una exposicion } \\
\text { de los proyectos del grupo, Aldo Rossi }+21 \\
\text { Arquitectos Espanoles }\end{array}$ \\
\hline HOLLAND & $\bullet 1958$ n.1, January \\
\hline Forum & School te Tuusula, arch. O Sipari, V. Rewell \\
\hline & $\begin{array}{l}\text { Neue tendenzen im schulbau, Felix von Cube, } \\
\text { Berlin }\end{array}$ \\
\hline GERMANY & $\begin{array}{l}\text { Bauen+Wohnen } \\
\text { S. Carlo di Muggiò, arch. Baffa, Drugman, } \\
\text { Rivolta }\end{array}$ \\
\hline ES Edilizia Scolastica & \begin{tabular}{l} 
Scuola Elementare a Biassono, arch. Paolo \\
\hline
\end{tabular} \\
\hline & \begin{tabular}{l} 
Fiore \\
\hline
\end{tabular} \\
\hline
\end{tabular}

\section{REFERENCES}

American School \& University. (1971). Building Ideas That Save Money: An In-depth Interview with Dr. Harold B. Gores and Alan C. Green of Educational Facilities Laboratories, Inc. American School \& University, 43, No. 6 (February), pp. 13-32.

http://www.worldcat.org/oclc/425365458 . In Marks, Judy (2009), A History of

Educational Facilities Laboratories (EFL), National Clearinghouse for Educational Facilities, Washington, DC, pp. 1-8. https://files.eric.ed.gov/fulltext/ED508011.pdf Armsey, James W. (1976). A Commentary on a Series of Grants by the Ford Foundation to the EFL, Inc. 1958 - 1975. Folder 467, box 47, 202.79.6, Arthur D. Trottenberg Collection, Ford Foundation Records, Rockefeller Archive Center. New York: Ford Foundation, pp. 3-15. In Lee, Joshua. (2019). Flexibility and Design: Learning from the School 
Construction Systems Development (SCSD) Project, London: Routledge, pp. 39—41. https://doi.org/10.4324/9780203732083

Arnold, Chris, and George Rand. (1979). Evaluation: A Look Back at the '60s' Sexiest System; SCSD and Two of Its End Products. AIA Journal 68, No. 4 (April), pp. 52-86. In Wallance, David. (2021). The Future of modular architecture. New York : Routledge, 2021, pp. 91-92 https://doi.org/10.4324/9781003031932

Ehrenkrantz, Ezra. (1969). What's Happening to SCSD—and Why. Nation's Schools 83, No. 4 (April), pp. 55-57. In Marks, Judy (2009), A History of Educational Facilities Laboratories (EFL), National Clearinghouse for Educational Facilities, Washington, DC, pp. 1-8. https://files.eric.ed.gov/fulltext/ED508011.pdf

Ehrenkrantz , Ezra. 1999. "Planning for Flexibility, Not Obsolescence.” Paper read at Urban Educational Facilities for the 21st Century (UEF-21), at New Jersey Institute of Technology. https://files.eric.ed.gov/fulltext/ED439596.pdf

Lee, Joshua. (2019). Flexibility and Design: Learning from the School Construction Systems Development (SCSD) Project, London: Routledge, pp. 39—41. https://doi.org/10.4324/9780203732083

English, F. W. (2005). The SAGE handbook of educational leadership: Advances in Theory, Research, and Practice. SAGE Publications, Inc., pp. 506-537. https://dx.doi.org/10.4135/9781412976091

Gavosto A. (7 May 2021), Scuola, si toccano i gangli anche se manca una visione d'insieme, Il Sole 24 Ore. https://www.ilsole24ore.com/art/scuola-si-toccano-gangli-anche-se-mancaancora-visione-d-insieme-AEr7zpG?refresh_ce=1

Gores, Harold B. (1970). Schools in the 70s-the Case of the Relevant Schoolhouse. The bulletin of the National Association of Secondary School Principals, Volume: 54 issue: 346, Educational Facilities Laboratories, Inc., in New York City, pp. 134-138. https://doi.org/10.1177/019263657005434617

Graves, Ben E. (1993). School Ways: The Planning and Design of America's Schools. New York: McGraw-Hill, Inc, pp. 100-180. ISBN 13: 9780070024687

INDIRE. (2013). Il modello 1+4 spazi educativi. https://www.indire.it/progetto/ll-modello-1-4-spazi-educativi/ 
Lee, Joshua. (2019). Flexibility and Design: Learning from the School Construction Systems Development (SCSD) Project https://doi.org/10.4324/9780203732083

Marks, Judy (2009), A History of Educational Facilities Laboratories (EFL), National Clearinghouse for Educational Facilities, Washington, DC, pp. $1-8$. https://files.eric.ed.gov/fulltext/ED508011.pdf

MIUR (June 2020), School Plan 2020-2021, Document for planning school, education, and training activities in all institutions of the National Education System. https://www.miur.gov.it/documents/20182/0/Piano+Scuola+21_22.pdf/212c8420-e07b7719-8c6c-e6e8f99b175a?version $=1.0 \& \mathrm{t}=1628260180226$

MIUR (2013), Nuove linee guida per l'edilizia scolastica. http://hubmiur.pubblica.istruzione.it/web/ministero/cs110413

Pearson, E. (1972). Trends in school design. Anglo-American Primary School Project, Schools Council., \& Ford Foundation. London: Macmillan. ISBN-13: 978-0333133262 